\title{
LA CASACIÓN CIVIL
}

Francisco Velasco Gallo

El recurso de casación, como medio tutelar del Derecho objetivo, con su primordial finalidad de propender a la recta aplicación de la ley y la uniformidad de la jurisprudencia, es institución relativamente moderna: su origen como tal se encuentra en el Decreto francés, posterior a la revolución de 1789.

Sobrevenida la Revolución francesa, constituidos los poderes de acuerdo con los principios pregonados por Montesquieu, la primera idea de los legisladores de entonces fue la de establecer una entidad cuya función tendiera a hacer respetar las normas dictadas por el poder legislativo, y destruir todo acto proveniente del poder judicial que las contraviniese. El 12 de noviembre de 1790 culminaron los debates referentes a un tribunal de casación, con el fin de invalidar «todos los procedimientos en los cuales las formas hubiesen sido violadas, y toda sentencia que contuviera una contravención expresa al texto de la ley».

El decreto de 27 de noviembre de 1790 , determinó las atribuciones y la competencia del tribunal, la manera de nombrar a sus miembros y el modo de proceder ante él.

Se organizó así, aun cuando no como parte del poder judicial, sino como apéndice del parlamento, un tribunal supremo encargado de defender la ley.

Fue, pues, la necesidad de la defensa de la ley contra las sentencias violatorias de ésta, lo que al principio determinó el fin primordial de la casación. 
En el Perú, se enuncia la casación en la Constitución de 1979. El artículo 241, dice: Corresponde a la Corte Suprema fallar en última instancia o en casación, los asuntos que la ley señala.

La tutela de la ley no es el fin único de la casación. El recurso se ha establecido también para lograr la unidad de la jurisprudencia, porque no menos importante que velar por la aplicación de la norma jurídica es la necesidad de la unificación de su interpretación. Como acertadamente lo asevera la doctrina, la tutela de la ley y la unificación de la jurisprudencia no constituyen dos fines distintos y separados del recurso de casación; corresponden más bien y en rigor jurídico a dos aspectos de una función única que se compenetran y combinan, dado que mediante la unidad jurisdiccional se consigue igualmente la recta aplicación de la ley, pues se evitan interpretaciones que sean contrarias a su verdadero sentido y alcance.

La defensa del Derecho sustantivo y la unificación de su interpretación, tienen por fundamento el interés público; pero la institución tiene también un interés privado, que consiste en resarcir el perjuicio inferido al particular por la sentencia.

De lo cual se sigue que la casación tiene dos fines perfectamente diferenciables: un fin principal, que por consistir en la tutela de la ley y en la unificación de su interpretación, reviste un carácter de eminente interés público; y un fin secundario, que mira al que concretamente persigue el recurrente y que, por lo tanto, se funda en un interés privado o particular.

No obstante su carácter secundario, el interés privado del recurrente es indispensable para que la casación opere; como no existe casación de oficio, a este recurso sólo puede llegarse cuando la parte agraviada con la sentencia acude a él, como una oportunidad adicional para la defensa de sus derechos que estime lesionados con el fallo.

Cuando por medio de la casación el recurrente impugna la sentencia que deniega, por ejemplo, la filiación, le asiste un interés muy particular y concreto: que se le enmiende el agravio inferido, y por tanto, se le declare la filiación. Pero si bien el interés privado del recurrente es necesario para poner en movimiento la actividad jurisdiccional de la Corte de Casación, ese 
mismo interés particular no es sin embargo el fin cardinal del recurso, el cual es la recta aplicación de la ley. 0

Según el artículo 386 del Código Procesal Civil, son tres las causales para interponer el recurso de casación:

a) La aplicación indebida o la interpretación errónea de una norma de derecho material, así como de la doctrina jurisprudencial;

(En este inciso está comprendido el caso de incompatibilidad entre una norma constitucional y una legal ordinaria, a que se contrae el artículo 236 de la Carta Fundamental.)

b) La inaplicación de una norma de derecho material o de la doctrina jurisprudencial; $o$

c) La contravención de las normas que garantizan el derecho a un debido proceso, o la infracción de las formas esenciales para la eficacia y validez de los actos procesales.

Analicemos cada uno de los casos.

La aplicación indebida de la ley se presenta cuando entendida rectamente la norma de derecho en su alcance y significado, se la aplica a un caso que no es el que ella contempla.

El quebranto de una norma sustancial, por aplicación indebida, ocurre cuando, sin embargo de interpretarla el juzgador en su verdadera inteligencia, la aplica a un caso que ella no regula; es decir, cuando se aplica al asunto que es materia de la decisión una ley impertinente.

Trantándose de la aplicación indebida de la ley, el juez puede incurrir en errores in judicando o in procedendo.

Los vicios in judicando son los yerros en que incurre el juez al dirimir el conflicto, sea porque elige mal la norma sustancial, lo que lo lleva a aplicar un texto impertinente, sea por aplicar el que corresponde, pero atribuyéndole un sentido o alcance que no tiene. 
Se presentan los errores cuando no se acierta en la calificación o definición jurídica del caso contenido en la norma elegida.

El quebranto o infracción de las normas de procedimiento, o reguladoras de la actividad procesal, genera los errores in procedendo. Si es cierto que estos vicios son, en principio, ajenos al objetivo propio de la casación, algunos de ellos, por su gran trascendencia en el fallo, conducen al pronunciamiento de una sentencia injusta (incompetencia, indebida representación de las partes, falta de notificación del demandado, etc.).

La interpretación errónea de la norma legal ocurre cuando, siendo la que corresponde al caso litigado, se entiende equivocadamente, y así se aplica.

Interpretar erróneamente un precepto legal es, pues, aplicarlo al caso que se juzga por ser el pertinente, pero atribuyéndole un sentido o alcance que no le corresponde.

La inaplicación de una norma de derecho material aparece cuando, al dictar la sentencia, el juez no la aplica, debiendo haberla aplicado.

En teoría, la falta de aplicación de la norma legal se traduce en un error sobre la existencia del precepto. A la inaplicación de la regla jurídica llega el juez, ora porque desconoce su existencia, o porque, partiendo de la existencia de ella, le desconoce validez en el tiempo o en el espacio.

Es evidente que la inaplicación significa, en todo caso, el desconocimiento de la verdadera voluntad del legislador, expresada en el precepto legal no aplicado.

La falta de aplicación requiere, como presupuesto indispensable, que sí debía haberse aplicado esa disposición.

La doctrina jurisprudencial vincula a los órganos jurisdiccionales del Estado, a tenor del artículo 400 del Código Procesal Civil, por lo que debe ser aplicada por el juez.

La contravención de las normas que garantizan el derecho a un debido proceso, exige el estudio de éste. 
En la época moderna se habla de las garantías del debido proceso, que en síntesis son las siguientes: que el demandado haya sido notificado debidamente; que tenga oportunidad de comparecer y de defenderse; que sea juzgado en la jurisdicción que le corresponde y por un tribunal imparcial.

Actualmente se distinguen dos clases de formas: unas sustanciales, mas importantes, y otras accidentales, menos importantes. La infracción de las esenciales, o sea, las sustanciales, restan eficacia y valor a los actos procesales. Constituyen una causal para interponer el recurso de casación.

\section{0}

Los procesalistas consideran también como causal de casación el contener la sentencia errores de derecho o de hecho, debidos a una equivocada apreciación de las pruebas.

El error de derecho es el yerro del juez en el momento de la apreciación de las pruebas, es decir, cuando dándoles por existentes en el proceso, pasa a valorarlas, y en esta actividad interpreta desacertadamente las normas legales. Por ejemplo, corre en autos la declaración de la parte, pero el juez al apreciarla la divide en perjuicio del declarante.

Es, pues, al evaluar la prueba existente cuando puede darse este yerro.

El error de hecho se presenta en dos supuestos:

a) Cuando el juez da por demostrado un hecho, sin existir en los autos la prueba de él. Sin existir, por ejemplo, prueba de la sevicia, el juez declara fundada la demanda por esta causal.

b) Cuando el juzgador no da por acreditado un hecho, a pesar de existir en el proceso la prueba idónea de él. El juez, por ejemplo, no da por acreditado el adulterio, a pesar de existir en el proceso la partida de nacimiento del hijo habido fuera del matrimonio.

Ingresado el expediente en la Corte Suprema, la Sala respectiva debe pronunciarse sobre la admisibilidad y la procedencia del recurso de casación. 
Si no se ha cumplido con los requisitos de forma, enunciados en el artículo 387 del Código Procesal Civil, declara nula la resolución que admitió el recurso.

El incumplimiento de alguno de los requisitos de fondo origina la declaración de improcedencia del recurso.

Declarado procedente el recurso, la Sala fija el día y la hora para la vista de la causa. La fecha fijada no será antes de los 15 días de notificada la resolución con que se informe a los interesados.

Tratándose de la decisión del recurso, el pensamiento jurídico sigue dos direcciones.

El sistema del reenvío, según el cual una vez que la Sala de casación pronuncia la sentencia, con ella se ha puesto término al recurso. La sentencia que debe reemplazar en el proceso a la que ha sido casada por el tribunal supremo, tiene que ser pronunciada por un juzgador de instancia, a quien se le remite el expediente. El Código Procesal Civil, en el artículo 396, observa un sistema ecléctico. Dictada la sentencia de casación, la Sala se convierte en tribunal de instancia, y pronuncia la resolución que debe reemplazar a la que ella misma ha casado.

El sistema del reenvío se consagra cuando la Sala casa la sentencia por haberse violado el derecho a un debido proceso, o se han infringido las normas esenciales para la eficacia y validez de los actos procesales.

En estos casos, la Sala dispone, al mismo tiempo, la devolución del expediente, con el objeto de que el tribunal o el juzgado de origen procedan a nuevo pronunciamiento; o bien anula lo actuado hasta el estado en que se cometió el vicio procesal; o, en fin, declara inadmisible o improcedente la demanda.

Lo escrito constituye los comentarios sobre la casación civil. 